\title{
AMPHIBIANS
}

\section{AN EXTENSION OF GRAY TREEFROG RANGE IN MANITOBA AND INTO SASKATCHEWAN}

\section{PETER TAYLOR, P.O. Box 597, Pinawa, MB, R0E 1L0; E-mail:<taylorp@granite.mb.ca>}

This is an unplanned sequel to an earlier article on Gray Treefrog distribution in west-central Manitoba, mostly in the northern Interlake region. ${ }^{4}$ Except for mentioning two previous specimen records near Cowan and Camperville, and a few speculative comments about areas adjoining Duck Mountain and the Porcupine Hills, that article did not cover the region west of Lake Winnipegosis. Shortly after it was published, however, Gray Treefrogs were reported calling near Pelican Rapids, Manitoba, in 1997 (Ron Hooper, pers. comm.). Pelican Rapids is at the south-eastern corner of Dawson Bay, which is the most northwesterly arm of Lake Winnipegosis (see Fig.1). In addition, there are two unconfirmed treefrog reports for Saskatchewan: one heard near Fort Qu'Appelle in 2007, and one that was reported as caught at Katepwa but neither kept nor photographed (Ron Hooper, pers. comm.).

Gray Treefrogs call at breeding pools on warm evenings, often starting around 6:00 p.m. and continuing until 11:00 p.m. or later. In the Pinawa area of southeastern Manitoba $\left(50^{\circ} \mathrm{N}, 96^{\circ} \mathrm{W}\right)$, individuals have been heard calling from 30 April to 6 September, with full choruses from 11 May to 5 July (these dates include the year-to-year variation between 1989 and 2005). ${ }^{3}$ The species has been heard in the northern Interlake region (north of $52^{\circ} \mathrm{N}$ ) as early as 19 May, and the peak calling period there appears to be the second half of June, with some calling into early July at least. ${ }^{2,4}$ Favoured breeding localities include borrow pits, ditches, and beaver swamps in forested areas, often adjoining highways, as well as natural, permanent wetlands in forested regions. Under good weather conditions at the right time of year, it is therefore possible to survey large areas for Gray Treefrogs in a few hours of road travel with frequent stops. In this way, I explored the limits of the species' range west of Lake Winnipegosis, with particular interest in determining whether the range extends into Saskatchewan.

\section{Survey Summaries}

I was fortunate to have good conditions (temperatures near $20^{\circ} \mathrm{C}$ with light winds and fairly high humidity but little or no precipitation) to conduct roadside surveys in several areas west of Lake Winnipegosis on one evening in June 2008 and three in June 2009. The areas surveyed, and the locations where Gray Treefrogs were heard, are mapped in Fig. 1, which corresponds roughly to the western half of Fig. 1 in Reference 4. The two lightly shaded, polygonal areas show the combined Manitoba and Saskatchewan provincial parks and provincial forests in the Duck Mountain and Porcupine Hills regions. Individual locations are identified on the map by a one- or two-letter code, and in the text by the same code in square brackets. Some 


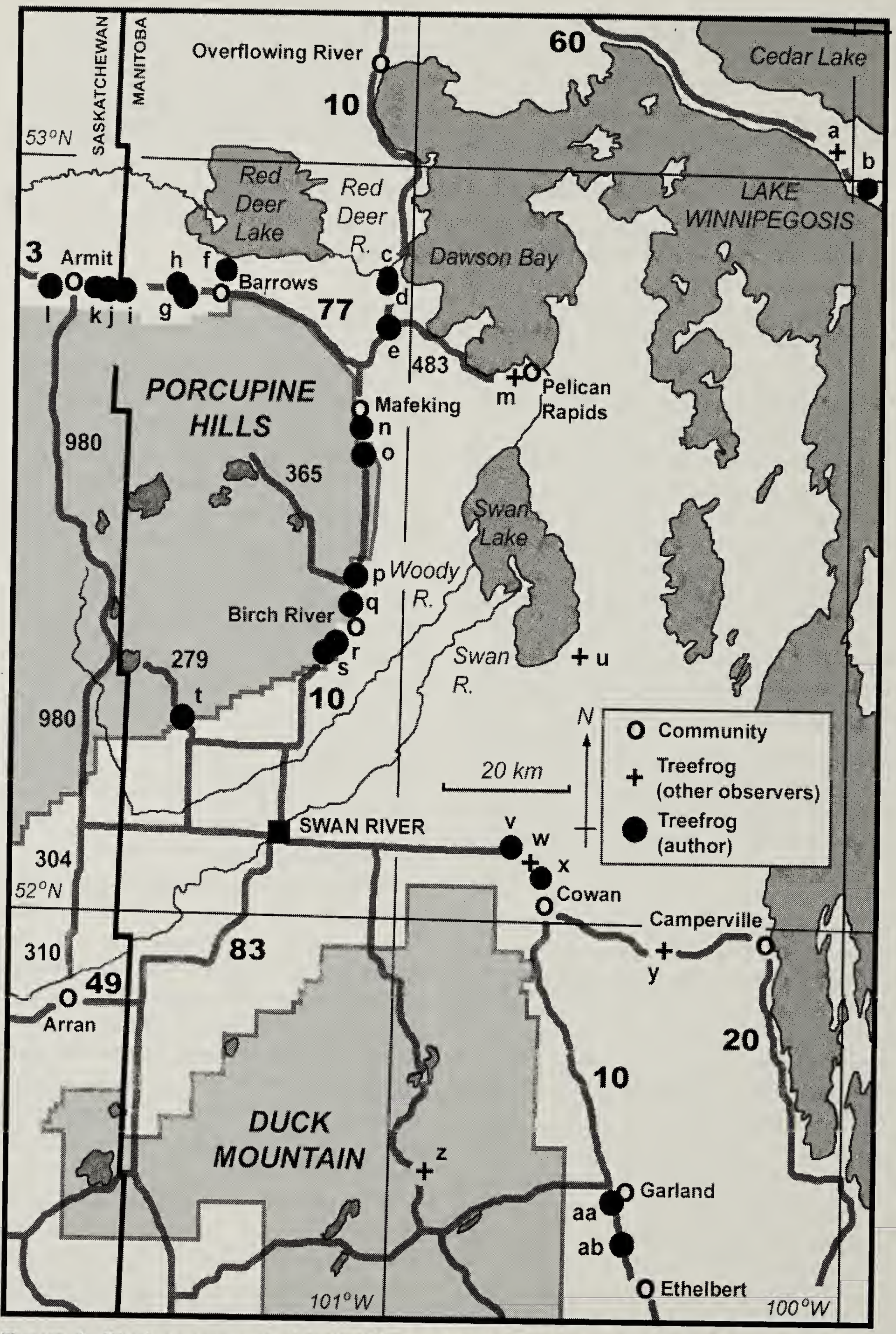

Figure 1. Study area west of Lake Winnipegosis showing records of Gray Treefrogs in Manitoba and Saskatchewan. 
multiple locations within $1 \mathrm{~km}$ of one another are represented by a single point, unless they are discussed separately in the text.

\section{Day 1, 23 June 2008}

While travelling south on Manitoba Highway (Hwy) 10, I detected Gray Treefrogs at a borrow pit on the west side of Hwy 10 [c], $2.2 \mathrm{~km}$ south of the Red Deer River bridge and $23 \mathrm{~km}$ north of Mafeking (according to a nearby road sign; other distances were measured by odometer). About six were calling strongly here at $6: 15$ p.m.; at least four were calling at a roadside pool about 0.5 $\mathrm{km}$ farther south [d], and one more was heard at a backed-up culvert $0.9 \mathrm{~km}$ south of the junction of Provincial Road (PR) 483 to Pelican Rapids [e].

I then travelled west on Hwy 77 from Hwy 10 to the Saskatchewan border, with a brief side-trip northward from Barrows to the south shore of Red Deer Lake, then continued on Saskatchewan Hwy 3 for about $8 \mathrm{~km}$ to Armit. The eastern half of Hwy 77 was disappointing, with no treefrogs heard in swampy areas at 0.7 and $3.8 \mathrm{~km}$ from Hwy 10 , after which the habitat was less promising, with heavily wooded but generally rolling and welldrained terrain. I had better luck near Barrows, with one treefrog calling at a farm dugout $3.3 \mathrm{~km}$ north on the Red Deer Lake road [ $\mathrm{f}$, then two calling at 7.2 $\mathrm{km}$ and two at $7.9 \mathrm{~km}$ west along Hwy 77 [g,h]. Finally, between 8:00 and 9:00 p.m., I detected two calling softly in roadside trees alongside Hwy 3, about 1.1 and 1.3 $\mathrm{km}$ west of the Saskatchewan welcoming sign [j]. The soft calling, away from water, suggested that they were not breeding that evening.

Around 10:15 to $10: 30$ p.m., I made several brief stops along Hwy 10 where it skirts the eastern edge of Porcupine Provincial Forest. Treefrogs were heard between $1.3 \mathrm{~km}$ north [p] and $2.4 \mathrm{~km}$ south [q] of the junction of PR 365 (Steeprock Lake road), and again between 9.8 and $11.5 \mathrm{~km}$ south of that junction [r,s], southwest of the community of Birch River. The treefrogs appeared to be generally distributed in areas of wet, level terrain with immature stands of aspen and willow or mixed-wood forest.

\section{Day 2, 24 June 2009}

Between 5:45 p.m. and about 8:00 p.m., I slowly drove about $25 \mathrm{~km}$ north from the $0 \mathrm{~km}$ sign at the south end of Saskatchewan Hwy 980, and back, without hearing any treefrogs. The most promising habitat (slow-flowing creeks and beaver swamps) was near the south end of this road and the adjoining few kilometres of Range Road 304, where numerous small tributaries of the Woody River originate. Farther north into the hills, there was little standing water in the rolling terrain.

I backtracked into Manitoba and explored side roads northwest of Swan River. Again there seemed to be suitable spots near some creeks, but much of the habitat was fragmented by extensive cropland. The only Gray Treefrogs I heard that evening were one or two individuals calling at a beaver swamp just inside Porcupine Provincial Forest along PR 279 (the Whitefish Lake road) at $52.262^{\circ} \mathrm{N}$, $101.476^{\circ} \mathrm{W}$ [t]. This is the most westerly treefrog location that I have found on the south side of the Porcupine Hills.

\section{Day 3, 25 June 2009}

While travelling from Pinawa to Swan River, I made several quick stops between 7:00 and 8:00 p.m. along Hwy 10 north of Ethelbert and due east of Duck Mountain. Gray Treefrogs were calling between Fork River and Garland River, about 8 and 14 $\mathrm{km}$ north of Ethelbert [aa, ab], but none was heard between Garland and Cowan. More were calling, however, at several 
locations between 6 and $9 \mathrm{~km}$ northwest of Cowan $[\mathrm{x}, \mathrm{v}]$; this area corresponds to one of F.R. Cook's two specimen locations $[\mathrm{w}]$, the other being midway between Cowan and Camperville [y]. 2,4

I revisited the southernmost few kilometres of Saskatchewan Hwy 980 (see Day 2, above) at about 9 p.m., then explored Range Roads 304 and 310 south to Arran, and Hwy 49 east to the Manitoba border, before returning to Swan River without further stops. No treefrogs were heard, and areas of seemingly suitable habitat were again relatively fragmented.

\section{Day 4, 26 June 2009}

I revisited some of the areas surveyed on Day 1 (see above), hoping to obtain sound recordings of Gray Treefrogs near the Manitoba-Saskatchewan border.

Travelling north from Swan River on Hwy 10 , I noted treefrogs at about 6:00 p.m. near Birch River $\left(52.372^{\circ} \mathrm{N}\right.$, $101.146^{\circ} \mathrm{W}$, close to the southernmost record on Day 1 [s]), then at two locations $[0, n]$ south of Mafeking $\left(52.621^{\circ} \mathrm{N}\right.$, $101.096^{\circ} \mathrm{W}$ and $52.670^{\circ} \mathrm{N}, 101.097^{\circ} \mathrm{W}$ ). I obtained a sound recording of a small breeding chorus (about three calling individuals) at the latter location, $1.4 \mathrm{~km}$ south of the Mafeking town-limit sign.

Heading west on Hwy 77, I recorded another small chorus at one of the Day 1 locations [g], about $7.2 \mathrm{~km}$ west of Barrows $\left(52.830^{\circ} \mathrm{N}, 101.548^{\circ} \mathrm{W}\right)$. The treefrogs were calling strongly and were audible from about $800 \mathrm{~m}$ along the highway. Farther west, a single treefrog was calling a few hundred metres east of the Saskatchewan border [i].

At $52.830^{\circ} \mathrm{N}, 101.700^{\circ} \mathrm{W}$, about 1.9 $\mathrm{km}$ west of the "Saskatchewan Naturally" sign, about four treefrogs were calling in a breeding chorus at about 8:30 p.m., and I was able to obtain satisfactory sound recordings [j]. The habitat was a dense strip of willows on the south side of the highway, with standing water in the ditch, in mostly coniferous (spruce and tamarack) forest.

About $4 \mathrm{~km}$ farther west $(1.4 \mathrm{~km}$ east of the junction of Saskatchewan Hwy 3 and $\mathrm{Hwy} 980$ ), at $52.834^{\circ} \mathrm{N}, 101.759^{\circ} \mathrm{W}$, three treefrogs were calling at a beaver swamp that was partly retained by the old Canadian National Railway right-of-way, immediately south of and parallel to the highway [k]. At this point, there is farmland to the northeast but continuous forest in the other three quadrants. A photograph of the habitat is shown in Fig. 2. Again, sound recordings were obtained. The treefrogs were still calling when I revisited the area at 10:40 p.m.

Finally, a single treefrog was heard in an extensive swampy area south of Hwy 3 west of Armit at $52.834^{\circ} \mathrm{N}, 101.816^{\circ} \mathrm{W}$ (my location on the highway), between the Little Armit and North Armit river crossings [I]; it was too far away to obtain sound recordings. No more treefrogs were found, although there appeared to be suitable habitat in places, between 9:30 and 10:30 p.m. along Hwy 3 west to the Red Deer River crossing near Erwood. A side-trip down the northernmost $7 \mathrm{~km}$ of Hwy 980 was also fruitless.

\section{Additional Records}

I received the following reports of Gray Treefrogs at previously unpublished localities in western Manitoba:

(a) One noted by Dauphin naturalist Bill Walley in the Chain Lakes area of Duck Mountain Provincial Park, 1 July 2008. The approximate location is indicated in Fig. 1 [z].

(b) Single individuals seen at $52.328^{\circ} \mathrm{N}, 100.616^{\circ} \mathrm{W}$ (near Kettle Stones Provincial Park, just south of Swan Lake), 7 July 2009 [u], and both seen and heard at $52.739^{\circ} \mathrm{N}, 100.715^{\circ} \mathrm{W}$ 


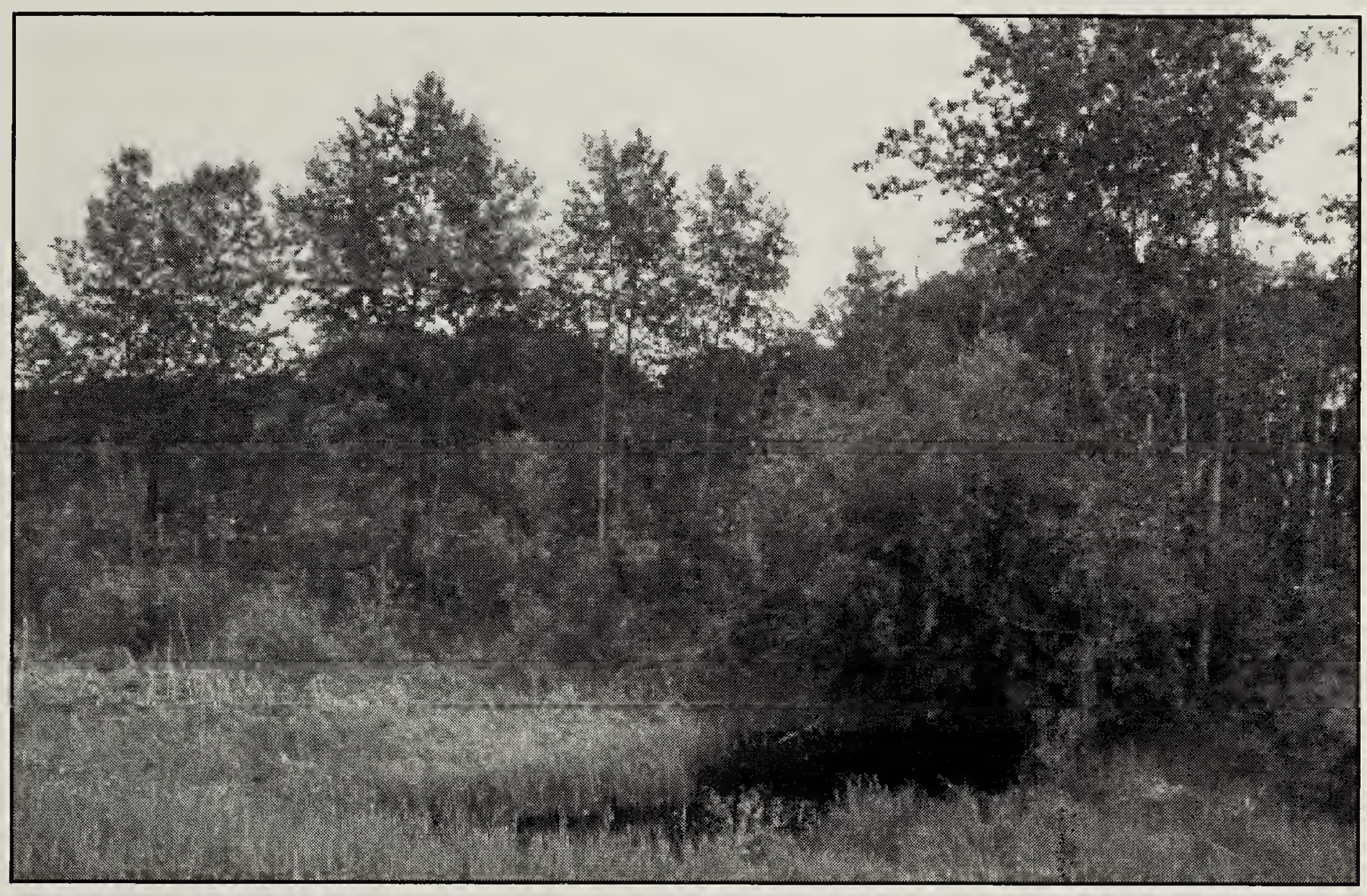

Figure 2. Gray Treefrog habitat alongside Saskatchewan Highway 3 east of Armit.

Peter Taylor

(near Pelican Rapids), 8 July 2009 [m], by Winnipeg-based naturalist Christian Artuso. Both locations are included in Fig. 1. The Pelican Rapids location is close to Ron Hooper's 1997 record, but exact coordinates for the latter are not known.

The occurrence of Gray Treefrogs along Hwy 60 north of Lake Winnipegosis, as described previously, ${ }^{4}$ was confirmed by Jim Duncan (manager of the Manitoba Conservation Data Centre), who noted one calling at $53.033^{\circ} \mathrm{N}, 100.055^{\circ} \mathrm{W}$ on the morning of 12 June 2009 [a]. This is about $8 \mathrm{~km}$ beyond the previous "farthest west" record on Hwy 60 at $52.987^{\circ} \mathrm{N}$, $99.968^{\circ} \mathrm{W}[\mathrm{b}] .^{4}$

Similarly, the presence of Gray Treefrogs along Hwy 6 south of Grand Rapids, as well as the easternmost portion of Hwy 60 (as described and mapped in Reference 4), was confirmed by Randy Mooi (Curator of Zoology at The Manitoba Museum, Winnipeg) in late June 2008 and 2009. His records extend the "farthest north" on Hwy 6 by about 7 $\mathrm{km}$, from $53.060^{\circ} \mathrm{N}, 99.225^{\circ} \mathrm{W}$ [ac] to $53.120^{\circ} \mathrm{N}, 99.254^{\circ} \mathrm{W}$ [ad]. The latter location was documented by a voucher specimen (MM933) in the Manitoba Museum collection, collected by Mooi on 23 June 2008 and shown in Fig. 3 (see inside back cover, top). Several individuals were also calling there on 26 June 2009. These localities [a, b, ac, ad] are mapped in Fig. 4, which is adapted from Fig. 1 of Reference 4 and includes a small area of overlap with Fig. 1. Note that locality [ac] was previously discussed in Reference 4 but overlooked when the original map was prepared.

Well within the known range limits, but filling gaps in the mapped distribution of records,${ }^{1}$ I heard Gray Treefrogs calling during the early evening of 10 June 2009 at numerous locations along a $50-\mathrm{km}$ stretch of Hwy 6 in the Camper-AshernGrahamdale-Hilbre area (between about $51.1^{\circ} \mathrm{N}, 98.3^{\circ} \mathrm{W}$ and $51.5^{\circ} \mathrm{N}, 98.6^{\circ} \mathrm{W}$ ). The following day, 11 June 2009, they 


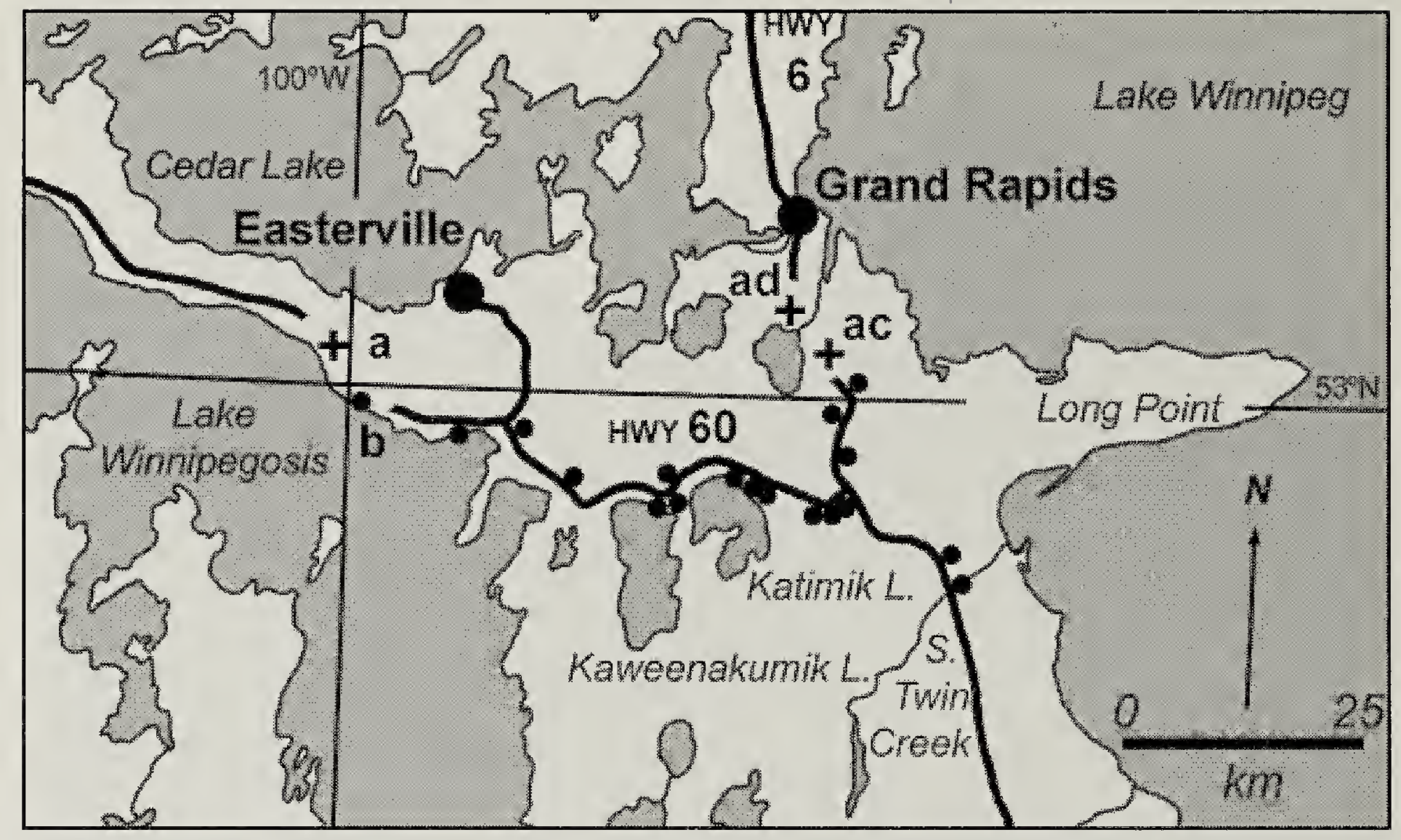

Figure 4. Northernmost records for Gray Treefrogs near Grand Rapids, Manitoba. Dots indicate previously mapped localities; "+" indicates new and previously unmapped localities.

were widespread along PR 513 between Gypsumville and the community of Dauphin River, on the western shore of Lake Winnipeg. They were especially numerous near the forested edges of the immense grassy marshes bordering the Dauphin River itself (about $51.9^{\circ} \mathrm{N}$, $98.3^{\circ} \mathrm{W}$ ), due north of the northern extremity of Lake St. Martin, but were relatively scarce farther east.

\section{Discussion}

This article documents an extension of the Gray Treefrog's known range northward to the fringes of the Porcupine Hills, and west as far as the Armit area of Saskatchewan. The species is quite widely distributed in low-lying areas near the eastern fringes of Duck Mountain and the Porcupine Hills, and there is one report from the heart of Duck Mountain (Fig. 1). South of the Porcupine Hills, the treefrogs seem to disappear just east of the Saskatchewan border. It is possible, however, that they occur in more southerly areas of eastern
Saskatchewan, for example in the western part of the Duck Mountain region or in the Qu'Appelle Valley.

The sound recordings made at two Saskatchewan locations $[\mathrm{j}, \mathrm{k}]$ on 26 June 2009 were sent to the Royal Saskatchewan Museum, and those from Manitoba and Saskatchewan locations $[\mathrm{g}, j, k, n]$ were sent to the Manitoba Museum. Curators at both museums confirmed the identity of the sounds, which appear to provide the first substantive evidence of Gray Treefrogs in Saskatchewan, as well as in the Porcupine Hills region of Manitoba ( $R$. Poulin and R. Mooi, pers. comm.).

The treefrogs show an affinity for regions of level, forested terrain where the water table is at or near the surface, and where potential breeding pools are created by both natural perturbations (e.g., beaver activity) and human activities (e.g., dug-out ponds, borrow pits, and drainage modification by rights-of-way). 
They appear to prefer more or less continuous forest, although in areas with large treefrog populations (such as my home area near Pinawa in southeastern Manitoba), some individuals may wander along ditches or through wetlands for a kilometre or more from forested areas.

Factors limiting the Gray Treefrog's range may include decreasing moisture to the west and south, and decreasing temperature to the north. Habitat fragmentation by agricultural development may limit treefrog distribution at the western fringe of the range, based on their apparent absence from much of the Swan River valley. It remains to be seen whether the range completely encircles Lake Winnipegosis, or whether the combination of glacial moraines and spruce bogs at the northern extremity of the lake comprise an effective barrier, as suggested previously. ${ }^{4}$ There appears to be suitable habitat near Manitoba Hwy 10 north of the Red Deer River, at least as far as Overflowing River.

While Gray Treefrogs show some preference for deciduous cover, the deciduous component at some localities was limited to young willows or aspens in disturbed areas of predominantly coniferous forest. The breeding localities along Hwy 10 south of the Red Deer River $[c, d]$ were situated in a large expanse of burned coniferous forest in the early stages of regeneration, where deciduous growth was limited to aspen and willow saplings plus a few small, surviving aspens.

As with many range extensions in sparsely populated regions, it is unknown whether the records described here represent an actual expansion of the population, the discovery of a long-standing population, or a sporadic fluctuation. Only further observations over a long period of time can resolve this uncertainty.

\section{Acknowledgements}

I thank Christian Artuso, Jim Duncan, Ron Hooper, Randy Mooi, and Bill Walley for the observations cited in this article, and Randy Mooi for permission to use his photograph of a treefrog.

1. PRESTON, W.B. 1982. The Amphibians and Reptiles of Manitoba, Manitoba Museum of Man and Nature, Winnipeg, Manitoba.

2. SCHUELER, F.W. and F.D. ROSS. 1986. Range extensions for hylid frogs in Manitoba. Blue Jay 44:168-173.

3. TAYLOR, P. 2006. Calling periods for frogs and toads near Pinawa, Manitoba, with an update on Mink Frog and Green Frog distribution. Blue Jay 64:44-55.

4. TAYLOR, P. 2008. Northward range extension for the Gray Treefrog in west-central Manitoba. Blue Jay 66:44-49.

The least movement is of importance to all nature.

The entire ocean is affected by a pebble.

- Blaise Pascal 